\title{
SRC Substrate Cortactin
}

National Cancer Institute

\section{Source}

National Cancer Institute. SRC Substrate Cortactin. NCI Thesaurus. Code C17689.

Src substrate cortactin (550 aa, $\sim 62 \mathrm{kDa}$ ) is encoded by the human CTTN gene. This protein is involved in the regulation of both the interactions between adherens junction components and cytoskeletal organization. 